\title{
Covid19, the Shifting from Shock to Long-Term Coexistence, what Sacrifices Anticipated?
}

\author{
Hamid Yahya Hussain* \\ Dubai Health authority, UAE \\ *Corresponding author: Hamid Yahya Hussain, Dubai Health authority, UAE
}

\begin{tabular}{|c|c|}
\hline ARTICLE INFO & Abstract \\
\hline Received: May 08, 2020 & Citation: Hamid Yahya Hussain. Covid19, the Shifting from Shock to Long-Term \\
\hline Published:慧 May 21, 2020 & $\begin{array}{l}\text { Coexistence, what Sacrifices Anticipated?. Biomed J Sci \& Tech Res 27(5)-2020. BJSTR. } \\
\text { MS.ID.004559. }\end{array}$ \\
\hline
\end{tabular}

\section{In Sighting Crisis Contexts}

It is now necessary for everyone to realize that the stage of shock caused by the COVID 19 is not resolved, yet it will do so shortly, which will not happen without high and painful price, this crisis remarkably uncovers the fragility status of the international system and hard to resilience capacity has that we all deceived by. The accumulated gains throughout decades and decades humankind added has been demolished down in weeks and days. , and revealed an absolute lack of preparedness and insight during the witnessed crisis, some of the countries were totally torn and collapsed with the at the very first challenge. The time has come for the emerging of a new world, with different capacities, values, and visions. In addition, uncertainty spaces need to be narrowing. The current question is should we go back to our normal life or shall we understand lessons deeply to develop a new world [1].

\section{How will Covid19 Change the World's Status?}

Thousands and millions of people around the world perhaps will be out of work. Enormous economy stimulus packages will be pushed by the national government ever in the present history. In certain places, property owners will not be collecting rent, or banks collecting mortgage payments and the homeless will be allowed to stay in hotels free of charge. Direct government Basic income provision trials will be executed. in the large swathes of the world will be collaborating-with various degrees of coercion and nudging - on a shared project of keeping at least two meters between each other whenever possible [2]. However, crises can also send societies down darker paths. , government surveillance of citizens exploded,

\section{Endless Questions to be Addressed}

As current crises shape our history, there are hundreds of thinkers who have devoted their lives to studying how they unfold.

Apparently, crisis studies fields revealed the potentials and the power to-mapping the way the community is laid bare, wherever and whenever likewise crisis placed in a given community, the fundamental scenario will be based on who have less and who have more [3]. What capacity and how long it stays. What fear people and what makes people treasured. In similar historical times, hunting small stories and images shall tragically reveal, what has been broken in the community, as just how broken it is, in the shape of tiny images and stories.

\section{The Crisis that is Shaping Current \& Future Life}

In recent weeks, the news has furnished us with countless examples. Airlines are flying large numbers of empty or near-empty flights for the sole purpose of protecting their slots on prime sky routes. There have been reports of police fining homeless people for being outside during the lockdown. Prisoners are getting paid less than a dollar per hour to bottle hand sanitizer that they themselves are not allowed to use (because it contains alcohol), in a prison where they are not given free soap, but must buy it in an on-site shop. However, disasters and emergencies do not just throw light on the world as it is. But tears the coherent fabric of normal life. Through opened up holes [4], possibilities of other worlds can be glimpsed. Many of crises insight lookers concentrate more on bad consequences scenarios. By making bad things even worse. In crisis times, particularly, tendencies to stepping up xenophobia and racial scapegoating remarkably increase. Recent publications e.g. Wikipedia revealed that incidences of "xenophobia and racism during 2019-20 Covid19 pandemic from even more than 35 countries" reported: "In a wise enough and civilized world, assumptions that global pandemic must drive to greater internationalism would be expected ", by accelerating up 
manufacturing of test kits, masks, and respirators, basic essential supplies-and spare then for poorer countries, not only rich.

\section{One Battle one World}

It is all one battle. However, it is not necessarily a rational world. Therefore, there could be a lot of demonization and calls for isolation. means more and more mortalities, morbidities, and worldwide suffering. "It claimed or implied that Covid-19 is a manmade bioweapon. Officials, in turn, have pushed the conspiracy theory that the outbreak came from Laboratories. In Europe, some officials declared "Europe e.g. fighting a two-front war: one front is called migration, and the other one belongs to the coronavirus. Both and each of them is movement spread phenomena. However, it is easy, in the rush of crisis, to put in place surveillance tools without thinking about the long-term harm they might do [5]. "The course of the crisis revealed paradigm-shifting to How to protect these companies so they can collect data's? Instead of 'How do we controlee such companies not to violating privacy norms and rights'

\section{COVID19 Bill}

One of the major parts of the Covid19 bill is to give police and immigration officers the authority - in place for the next two yearsto arrest and suspected Covid19, infected people, to enforce testing. Similar rules shall allow judges to exempt courtrooms in the context of emergency times, leading to a status of people being put in jail even without given an opportunity to object formally [6,7]. These powers are put in place, and it sounds reasonable enough at the time-and then very quickly they are applied for other purposes that have nothing to appreciate public safety and democracy.

\section{Addressing Public Health by Governments}

"Government needs to address public health problems using mindsets more appropriate for tracking down criminals. Likewise, confused mindset ended up most impacting poor and racial minorities. Tactics like these can make fighting the disease harder, by driving a hard wedge of distrust between government and citizens. As the report put it: People, rather than the disease, become the enemy. "With the broad public giving up a great deal while a small few profited - Covid-19 might open the door to political progress [8].

\section{New World}

The question of is this: Covid-19 has revealed the political status quo to be broken. Long before anyone had heard of the news is this: Covid-19 has revealed the political status quo to be broken. Previous to the era of Covid19, people used to die of kind of diseases that we used to deal with their treatment and prevention. For a long time, People experienced risky lives in community's colored with wealth. Crisis threats have been told long back by experts to be on the doors, like pandemics, yet preparedness strategies were not put in a place for long. "Healthcare to basic living expenses such as housing -even if the world has its problems, expansive government intervention is not a feasible solution. Instead, it has been told that what works best are "marketplace" solutions, which give large roles to corporations motivated not by outdated notions like "the public good" but by a desire to make a profit. As Covid19 outbreak started to spread out, national authorities pushed billions in days -farther to that, cheques to citizens have been directly delivered, what was feasible From this perspective, the task today is not to fight the virus in order to return to business as usual, because business, as usual, was already a disaster [9]. Optimistic thinkers realized that there is a big hope that we might start to see the new world. To fight thecovid19, to transform the business into something more secure and humane.

\section{Global Burdens}

In spite of being the biggest global crisis since the Second World War, Covid19 is still tiny comparing to long-run changes of climate as both challenges look as if sharing similarities. Both shall necessitate a significant threshold of global collaboration. The two of them required radical behavioral changes in today's practices to reduce tomorrow suffering [10]. It has been pointed out and predicted for a long time back, with obvious certainty by scientists, nevertheless have been ignored by official authorities, who were unable to look beyond the nearest fiscal quarter's growth statistics. Accordingly, both will require governments to take drastic action and banish the logic of the marketplace from certain realms of human activity, while simultaneously embracing. Now the challenge is to maintain crisis signs activated about climate, while the risks are orders of magnitude greater. It is not feasible to believe that we can't go 'back to normal', as all things weren't so." the burdens of climate change are more gradual than those of Covid-19. Most people do not feel they or their loved ones could die from the climate crisis this month, and so emergency mode is harder to activate and sustain., if we really believe that we are in a climatic crisis, The news continuously updating about which countries were declining their emissions the fastest, and people are clamoring to be certain that their leaders were implementing the policies that operating out effectively.

\section{Understanding Contexts}

However, it is not unimaginable that the experience of Covid-19 could help us understand climate change differently. As the virus has reduced industrial activity and road traffic, air pollution has plummeted. a particularly harmful pollutant that attacks the heart and lungs. It is estimated that, in China alone, emission reductions since the start of the pandemic had in effect saved the lives of at least 1,400 children under five and 51,700 adults over 70. Meanwhile, people around the world have been sharing their own anecdotal findings online - stories of sweet-smelling breezes, expanded bike lanes, and birdsong returning to neighborhoods -people catching signs, in the midway of catastrophe, about known and wanted future. 


\section{Hope Signs}

In parallel to all hopeful signs, which fits Covid-19. Disaster, the dismantling of even the meager currently applied rules designed to protect the atmosphere. In realizing the effect of the pandemic on the workforce, violation of pollution regulation will not be punished as far as firms can link likewise violations to the Covid19 emergency. Ministry of Environment in china already began waiving such monitoring, which evaluate the environmental burdens of industrial factories. In addition, advocacy groups funded by the plastics industry have launched a public relations blitz on behalf of single-use plastic bags, spreading the unproven claim that the virus has a low probability to adhere to plastic compared to fabric clothes of reusable bags. During the 2008 crisis, the emissions dropped down significantly, yet rebounded remarkably in 2010 -2011.

\section{Lessons Learned}

One of the brilliant lessons of the covid19 emergency is the energy of shared thoughts and emotions, which has accelerated radical reaction to bring the pandemic spread down. "The good lesson to be learned so far is that humankind needs to scare and shocked to together, to respond adequately to what we're terrified about. Thus, solely governments can be obliged to do. "It's of high advantage to entering an emergency mode of Covid19," "yet, unless otherwise to make with climate. It is clear to everybody that the Covid19 pandemic showed the utter bankruptcy of specific approaches to the economy "full of loss and vagueness." Can we stop the world from going back to a version prior to Covid-19, the progress in beating Covid19 still need more focusing without forgetting old ongoing disasters that are not yet unfolded?

\section{Epidemic Outcome}

"The political outcome of the epidemic needs to get analysis out in the world any way we can." One major obstacle is social distancing, which certainly hinders many time-tested methods of waging such struggles, such as political canvassing and street protest. "The biggest risk this time" "exclusion people, leave them sitting home, excessively handling social media, and extremely restricted forms to politics forms that get there enabled."

ISSN: 2574-1241

DOI: $10.26717 /$ BJSTR.2020.27.004559

Hamid Yahya Hussain. Biomed J Sci \& Tech Res

This work is licensed under Creative Commons Attribution 4.0 License

Submission Link: https://biomedres.us/submit-manuscript.php

\section{'It's knife's Edge we're Walking'}

What will evolve next, might link to the optimists' capacity to translate such times of Coalescence into the wider political horizon, debating that it brings no sense to handle Covid-19 beyond fixing everything else, to sharing resources with more people. "There is no language for this emotion, in which the wonderful comes wrapped in the terrible, joy in sorrow, courage in fear," it is like Paradise Built in Hell. "It is not possible to welcome disaster, but the responses can be valued, both practical and psychological." The world feels awfully strange right now, but not solely because -- it is fastly changing so fast and any one of and no one could fall sick at any moment, or carrying already the virus without knowing. The last few months of the Covid19 pandemic experienced extremely strange through uncovering a truth that, major events can possibly be changed, at any time. This truth, keep threatening both stability and liberty, can be simply forgotten. We are not observing a movie: we are contributing to the end together.

\section{References}

1. Abdullah Z (2020) COVID-19 to have 'significant' impact on economy: PM Lee Hsien Loong. CNA.

2. Tiezzi, Shannon (2020) China and Cambodia: Love in the Time of Coronavirus.

3. (2020) Limited, Bangkok Post Public Company Baht hits 7-month low as China virus threatens tourism. Bangkok Post.

4. Roidila MR (2020) 10,000 Chinese tourists cancel trips to Bali over coronavirus fears: Travel group. The Jakarta Post.

5. (2020) The Jakarta Post Panic buying hits Jakarta supermarkets as govt announces first COVID-19 cases-City. The Jakarta Post.

6. Ganeshwaran K (2020) Wuhan virus fears infect Malaysian economy. The Star.

7. Jonny L (2020) Coronavirus sees Chinese teams pull out of Tour de Langkawi and all riders subjected to health-screenings. Cycling Weekly.

8. Kenneth C (2020) List of KL concerts postponed due to Covid-19. The Star. Kuala Lumpur.

9. (2020) Saudi Arabia halts travel to Mecca, Medina over coronavirus. Www.aljazeera.com.

10. (2020) MWC hangs by a thread after Nokia, DT and other big names back out. Tech Crunch.

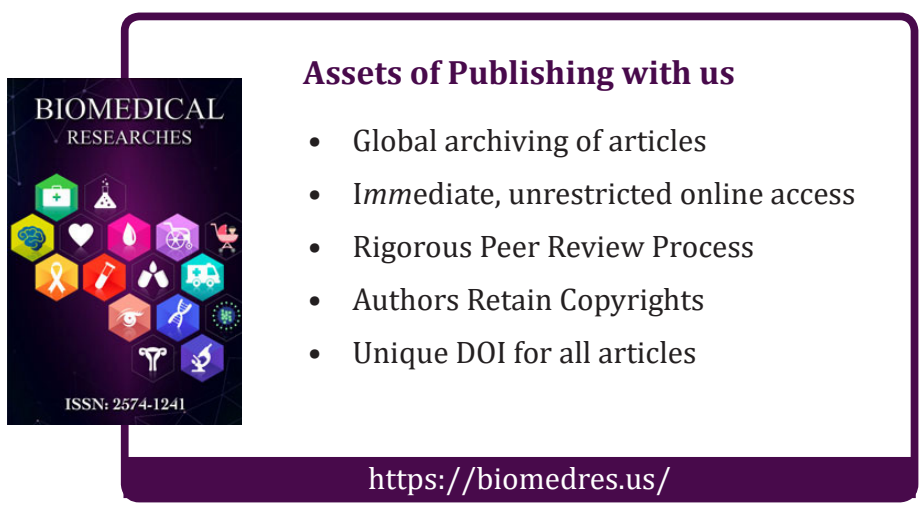

Copyright@ Hamid Yahya Hussain | Biomed J Sci \& Tech Res | BJSTR. MS.ID.004559. 